\title{
The relationship of the elderly toward their home and living environment
}

Housing is a basic human good and right. It plays a versatile role, allowing people to fulfil a number of needs, and it is not limited only to one's immediate living space, but also includes an individual's wider living environment. People's relationship toward housing and their living environment changes over the course of their lives. Especially in old age, housing becomes more important. Research shows that the elderly want to remain in their home environments as long as possible because they are closely attached to them. In order to determine whether these findings also apply to Slovenia, this article analyses how attached the elderly in Slovenia are to their homes and wider living environment and how satisfied they are with living there. The elderly's views were obtained with a survey, and a statistical analysis was carried out using SPSS software, based on the calculation of various statistical correlation tests. The analysis confirmed the assumption that the Slovenian elderly are also very attached to their homes or home environments and are satisfied with living there. In addition, the analysis showed some differences among the elderly in this regard depending on their age, where they live and how long they have been living in their current homes.

Keywords: population aging, housing, living environment, satisfaction, attachment, aging in place 


\section{Introduction}

The right to housing is a fundamental human right. According to Scott Leckie (1994), appropriate, affordable and accessible housing is generally accepted as a basic component of life in peace, dignity and safety. Srna Mandič (2011) argues that housing is undoubtedly among the most important factors of people's quality of life and welfare, which has also been acknowledged in the social sciences (Erikson, 1993; Atkinson et al., 2002; Fahey et al., 2004; Domanski et al., 2006; Daly, 2007) as well as in many international policy documents, which has been highlighted by many authors (Barlow \& Duncan, 1994; Kleinman et al., 1998, 2013; Doling, 1999, 2006; Milligan, 2003; Czischke \& Gruis, 2007). However, the role of housing in people's wellbeing is multidimensional. Specifically, housing comprises many features, including physical properties (size, infrastructure, etc.) and others that are more difficult to measure (location, service accessibility, good neighbourly relations, etc.; Mandič, 1996). One's living environment is not limited only to a housing unit, but also includes the immediate and wider community. According to Björn Hårsman and John M. Quigley (1991), housing is the most complex good, which is why, as Mandic (2011) points out, it is impossible to capture all of its meanings in relation to an individual. This has already been highlighted by Peter Marcuse (1987: 232), who wrote that "housing is more than just housing."

Housing fulfils people's physical, psychological and social needs, which Mandič (1996) applies to Erik Allardt's (1993) tripartite classification of needs into "having-loving-being". "Having" refers to the housing properties that determine the quality of housing as a material source (this involves the standard of living) and make it possible to fulfil biological needs. "Loving" is about housing fulfilling the human need for social contact, partnership, creating a separate household and family, integration into the local community and so on. "Being" is about housing meeting the need for self-realisation and expression of an individual's personal identity and improvement; this need is connected with the symbolic function of housing: with its looks, location and other features, housing reflects an individual's "profile" in society. Hence, housing is a "physical and social space that individuals control, in which they express their personal identity, privacy, and safety" (Saunders, 1990: 39). Here, the need for safety refers to the "ontological feeling of safety, to space in which people feel safe" (Boškić, 2002: 21). It is one of those human needs that is of exceptional importance for people's functioning in society. On the other hand, the need for privacy is related to satisfying primary needs. Housing as a space a person can retreat to makes it possible for people to feel at home. Through people's individual definition, housing as a "home" is the centre of family life, a place of freedom, independence, individuality, self-expression, and social status, and a support for work and leisure activities (Somerville, 1997). According to Peter Saunders and Peter Williams (1988), it reduces the feeling of alienation, disempowerment and fatalism in modern society.

People's relationship toward their home changes over the course of their lives and gains special importance in old age (Mandič, 2011). According to Frances Heywood et al. (2002), the elderly associate their home with numerous memories and identity, Anna Dupuis and David Thorns (1996) argue that they associate it with what they have achieved in life, and according to Roger Clough et al. (2004) they also associate it with the social network they have built in their living environment. Ivan Štuhec and Maksimiljan Fras (2010) report that the life of the elderly focuses on their home and immediate surroundings, which shows that they are extremely attached to their living environment. In order to establish whether these findings regarding the attachment of the elderly to their living environment also apply to Slovenia, this article analyses part of the results of a study conducted within the project Innovative Forms of Living Environments for the Elderly in Slovenia (Sln. Inovativne oblike bivalnih okolij za starejse v Sloveniji). It explores how attached the elderly in Slovenia are to their homes and wider living environment, and how satisfied they are with living there. The assumption is that in Slovenia, too, the elderly are closely attached to their homes or home environments and that they are satisfied with living there. In addition, there may be some differences among the elderly in this regard depending on their age group, the environment they live in (urban vs. rural), tenure (homeownership vs. rental), the type of housing they live in (house vs. apartment) and how long they have been residing in it.

\section{Theoretical background}

According to the broadest definition, home attachment is an emotional bond between an individual and his or her environment (Jorgenson \& Stedman, 2001; Brown \& Raymond, 2007). However, because this conception is very broad, researchers have divided home attachment into place dependence (Williams \& Vaske, 2003), attachment to neighbourhood (Sampson, 1988), place identity (Williams et al., 1992), social ties (Kyle et al., 2005), rootedness (Tuan, 1980; Hay, 1998), genealogical and economic attachment (Mishra et al., 2010) and emotional attachment (Kyle et al., 2010). Various authors have also explored what home attachment means in the methodological sense (Trentelman, 2009; Lewicka, 2011; Hernandez et al., 2013), especially when one wants to measure its intensity. According to some (Shamai, 1991; Lalli, 1992; Williams et al., 1992; Moore \& Graefe, 1994; Bricker \& Kerstetter, 
2000; Kyle et al., 2005), this intensity primarily depends on the extent and amount of contact individuals have with their living environment.

Charis E. Anton and Carmen Lawrence (2014) argue that the level of home attachment intensity can have positive and negative effects. On the one hand, great attachment is believed to be connected with good health and participation in the community. Individuals that are more attached to their homes and environment report greater social participation in the local community (Mesch \& Manor, 1998), which has a significant impact on the development of the community. In addition, home attachment can improve the quality of life (Harris et al., 1995) as well as psychological and physical health, it results in better social ties and it influences one's general satisfaction with the wider living environment (Tartaglia, 2012). On the other hand, individuals that do not develop an attachment to their homes or only at a very low level report higher stress levels and poorer health (Stokols \& Shumaker, 1982). However, Mark Fried (2000) argues that a high level of home attachment can also have a negative effect, especially among the elderly. In the event of poor health and other circumstances in which their living environment is no longer suitable, (overly) strong home attachment often prevents the elderly from moving into more suitable living environments that would improve their quality of life. Excessive home attachment may also be manifested in staying at home too much and in reduced social contact, which can lead to isolation. It is alarming that the Slovenian elderly spend an average of only 2.5 hours a day outside their homes (Štuhec \& Fras, 2010).

Various studies have proven that the elderly are extremely attached to their living environments and want to remain in them as long as possible. Among these studies, the survey conducted in 2005 by the American Association of Retired People (Salomon, 2010) is the most relevant. According to its findings, $89 \%$ of people over fifty reported that they wanted to stay at home as long as possible and retain their independence. An even more detailed survey performed by this association showed that the share of people that have such preferences increases with age (Salomon, 2000). Specifically, $75 \%$ of people between the ages of forty-five and fifty-four wish to remain in their homes as long as possible, $83 \%$ of those between fifty-five and sixty-four, $92 \%$ of those between sixty-five and seventyfour, and a full $95 \%$ of those over seventy-five. As reported by Emily Salomon (2010), elderly people would very much like to stay in their community or neighbourhood (i.e., a familiar living and social environment) even if they are no longer able to live independently. According to the survey by the
American Association of Retired People that the author refers to, the share of such respondents was 85\%. In Salomon's opinion, social connections with friends and neighbours, familiarity with local amenities and proximity to services are among the many things that they elderly would "lose" if they had to move elsewhere. Accordingly, they do not even want to think about moving (see e.g., Kerbler, 2014). This was also confirmed by Peter de Jong et al. (2012), who established that home attachment is often reported as one of the main reasons for the extremely low mobility among the elderly. Homeownership plays an important role in this; for Slovenia this has also been confirmed by Richard Sendi et al. (2003). The majority of the elderly that would be willing to move elsewhere lived in rented housing. The share of homeowners that would be willing to move was much smaller. The significance of this finding can be further underlined and additional justification for the present analysis of the elderly's attachment to their homes can be provided by the results of the Survey of Health, Ageing and Retirement in Europe (SHARE; see Mandič, 2015), which show a strong predominance of homeownership over rentals among the elderly in Slovenia (elderly Slovenian households are ranked third among all SHARE countries in terms of the share of homeownership). Hence it can be concluded that the elderly in Slovenia are extremely attached to their homes and are unwilling to move elsewhere.

Stephen M. Golant (1982) argues that, in addition to home attachment, dwelling satisfaction is also a predictor of residential relocation and preferences, as well as a subjective indicator of the quality of life. Dwelling satisfaction depends on various factors relating to an individual, such as health and potential impairment, neighbourhood contacts and safety. In addition, it is also influenced by housing characteristics, such as quality and size, and the subjective assessment of safety (Hwang et al., 1999). The amount of individual space available is also important and affects health and consequently satisfaction (CostaFont, 2013). According to Štuhec and Fras (2010), housing satisfaction is key to the quality of life, especially that of the elderly. As they report, research shows that "the elderly that are satisfied with their housing plan their future more positively, are more physically, psychologically and socially active, have more social contacts, and experience their everyday lives more positively" (2010: 6). According to Štuhec and Fras, the elderly report the need for safety and independence as the two most important needs related to living and satisfaction and, according to Paula Vasara (2015), they also highlight the need for peace, proximity to nature, and access to services and leisure activities. 


\section{Methods}

\subsection{Data collection and sample}

As part of the study described in the introduction, the data for the analysis were obtained through a survey. The Public Opinion and Mass Communications Research Centre of the Social Sciences Institute at the University of Ljubljana's Faculty of Social Sciences was commissioned to carry out the survey in November 2015. It involved computer-assisted telephone interviews, which included Slovenians aged fifty or more, both men and women, from all statistical regions and all settlement types (urban and rural). The final number of questionnaires completed was 930 , which accounts for $0.11 \%$ of the total Slovenian population age fifty or more.

The survey contained questions related to the real estate and households the respondents lived in (tenure, size, length of residence, maintenance problems, the real estate's adaptation to living in old age, number of household members, proximity of relatives, etc.) and questions referring to the respondents' economic status and health. The authors were also interested in the respondents' satisfaction with their housing and living environment, their attachment to their immediate living environment (home) and their wider living environment (neighbourhood or the environment they live in), and their attitudes toward potential relocation, the types of assistance they receive or would require for performing specific activities, their attitudes toward various living environments for the elderly with an emphasis on forms of living that are less common or not yet present in Slovenia, and their views on various housing solutions that make it possible to earn additional income from owning real estate. Finally, the respondents were also asked to provide information on their age, sex, education, marital status and place of residence.

Table 1 presents the selected sample characteristics that the authors wanted to statistically analyse to verify whether there were any statistically significant differences among the elderly in terms of their home attachment and housing satisfaction. The average age of respondents was 69.3 years and they had lived in their homes for an average of 36.5 years. Among the respondents in rural settlements, $69.8 \%$ lived in a compact rural settlement or its vicinity and $30.2 \%$ lived in a dispersed rural settlement or an isolated location. Among those in an urban environment, $54.7 \%$ lived in a small town and $45.3 \%$ lived in a large town; more than half of the latter (56.7\%) lived in Ljubljana or Maribor. Among homeowners, 74.8\% lived in houses and $25.2 \%$ in apartments.
Table 1: Selected respondent characteristics.

\begin{tabular}{|c|c|c|}
\hline Variable & Class/Group & Share (\%) \\
\hline \multicolumn{3}{|c|}{ Age (years) } \\
\hline & $50-59$ & 18.8 \\
\hline & $60-69$ & 32.5 \\
\hline & $70-79$ & 30.5 \\
\hline & 80 or more & 18.3 \\
\hline \multicolumn{3}{|c|}{ Settlement type } \\
\hline & Rural & 46.3 \\
\hline & Urban & 53.7 \\
\hline \multicolumn{3}{|l|}{ Tenure } \\
\hline & Homeownership & 97.9 \\
\hline & Rental & 2.1 \\
\hline \multicolumn{3}{|c|}{ Years in living environment } \\
\hline & 10 or less & 6.2 \\
\hline & $11-20$ & 11.6 \\
\hline & $21-30$ & 18.6 \\
\hline & $31-40$ & 28.0 \\
\hline & $41-50$ & 20.4 \\
\hline & 51 or more & 15.2 \\
\hline
\end{tabular}

\subsection{Selected variables}

In order to analyse the issue at hand, the focus was on the questions connected with the respondents's satisfaction with and attachment to their homes or living environment. To determine the attachment, attention was directed to the respondents' attachment to their housing and their attachment to the neighbourhood or the environment they live in. In some cases, both aspects were combined into what is referred to here as "general attachment". When establishing satisfaction, in addition to general satisfaction, the analysis focused on the respondents' satisfaction with their housing, the environment they live in, the physical accessibility of the living environment and the proximity of services and eldercare in this environment.

Each of the four satisfaction categories had already been subdivided into individual aspects in the survey itself:

- In terms of the respondents' housing satisfaction, the authors examined their satisfaction with the a) layout of rooms, b) size and c) construction quality;

- In terms of the environment the respondents live in, the questions focused on their satisfaction with d) the general orderliness of the environment, e) the peacefulness of the environment, $\mathrm{f}$ ) air quality in the residential area and g) its safety; 
- In terms of physical accessibility, the focus was on satisfaction with h) "external" accessibility or accessibility of the building they live in (e.g., transport, road and parking) and i) "internal" accessibility or accessibility of their apartment (e.g., lifts, stairs or other architectural barriers);

- In terms of the fourth category, respondents reported how satisfied they were with j) the proximity of their relatives and friends, $\mathrm{k}$ ) the proximity of healthcare, l) the proximity of long-term eldercare (e.g., homecare), $\mathrm{m})$ opportunities for recreation and socialising close to their homes and $\mathrm{n}$ ) the proximity of public amenities and services (e.g., shops, post offices and buses).

The respondents were asked to rate the level of satisfaction with their (immediate or wider) living environment on a scale from one to five $(1=$ very dissatisfied/unattached, $2=$ not satisfied/attached, $3=$ neither dissatisfied/unattached nor satisfied/attached, $4=$ satisfied/attached and $5=$ very satisfied/ attached). They could also choose "I don't know" or were not even required to provide an answer at all. As evident from Table 2, the majority nonetheless provided ratings.

\subsection{Methods and procedures used for the statistical analysis}

Even though the five-point Likert scale described is ordinal, for the purposes of the statistical analysis in this study it was treated as an interval scale; ${ }^{[1]}$ in addition, "I don't know" answers were also excluded from the analysis as well as those respondents that provided no answer to a specific question. Statistical analysis was conducted using SPSS for Windows 23.0. Alongside the basic statistical calculations (shares and averages), various statistical tests were calculated in order to obtain answers to the research questions posed and check the authors' conclusions and assumptions. To determine whether the average value of a selected variable differed between two groups of units, an independent samples $t$-test was used, and for more than two groups a variance analysis was applied. Various procedures were selected for the variance analysis in order to determine the statistically significant difference in the average value of a specific variable, depending on the group size and the fulfilment of the homogeneity of variance assumption. Following the guidelines by Andy Field (2009), the REGWQ procedure or Tukey's HSD was used if the groups were of the same size, Gabriel's procedure if their sizes were slightly different and Hochberg's GT2 if the group sizes differed significantly. If the assumption of the homogeneity of variance was not fulfilled, the Games-Howell procedure was used; prior to this, equality of group variances was tested using the robust Brown-Forsythe and Welch tests instead of variance analysis. The correlation between two nominal variables was checked using Pearson's chi-squared $\left(\chi^{2}\right)$ test and, if correlations were established, the intensity or level of correlation between the two variables was determined using the contingency coefficient $C$ or Cramer's $V$. The Pearson correlation coefficient $(r)$ was calculated if a correlation was established between two interval variables. The average values are referred to in this article as $M$ and the statistical differences $(p)$ are considered significant at 0.01 or 0.05 . For greater transparency, only the final statistically significant results are presented.

\section{Results and discussion}

Vasara (2015) argues that in general the elderly are very satisfied with their housing, which was also confirmed by the survey results. Specifically, the respondents reported that they were very satisfied with their immediate and wider living environment and that they were very attached to it. The average satisfaction rating with all aspects of housing and living environment was 4.14 and the average attachment rating to the elderly's home and living environment was even higher: 4.31. As shown in Table 2, among all of the attachment and satisfaction aspects evaluated, respondents rated attachment to their homes (housing) the highest, even though they were less satisfied with the housing aspects (layout of rooms, size and construction quality) than with others; the average rating was even below the overall satisfaction average (it stood at 4.07), in which construction quality was rated the lowest. On the other hand, the elderly ascribed the highest satisfaction ratings to aspects connected with their living environment $(M=$ 4.24), even though they were less attached to it than to their housing. According to Anton and Lawrence (2014), this is due to the fact that homes have more clearly defined space and boundaries, whereas a neighbourhood is a less clear concept. Among all of the aspects of satisfaction with the living environment, satisfaction with its safety and peacefulness stands out the most. In addition to their living environment, the elderly reported above-average satisfaction with its physical accessibility $(M=4.22)$, in which their satisfaction with accessibility within the wider living environment was significantly greater than with accessibility of their apartments. They were the least satisfied with the proximity of services and care in their living environment $(M=4.06)$ - all aspects of this category had a below-average satisfaction rating. The lowest rating of all was ascribed to the accessibility of long-term care services, but it should be noted that the number of replies to this question was also the lowest: nearly $18 \%$ of respondents did not rate this aspect at all. A relatively large share of no replies or "I don't know" answers (7.3\%) was also recorded for opportunities for recreation and socialising near home. The satisfaction rating for this aspect was also below average. 
Table 2: Average ratings, shares of ratings of 4 and 5, and combined share of these two ratings by individual aspects of attachment and satisfaction.

\begin{tabular}{|c|c|c|c|c|c|}
\hline Category and aspects & $\begin{array}{l}\text { Average rating } \\
\text { (M) }\end{array}$ & $\begin{array}{l}\text { Rating } 4 \\
(\%)\end{array}$ & $\begin{array}{l}\text { Rating } 5 \\
(\%)\end{array}$ & $\begin{array}{l}\text { Combined } \\
(\%)\end{array}$ & Rank* $^{*}$ \\
\hline \multicolumn{6}{|l|}{ Attachment to: } \\
\hline Home & 4.41 & 21.5 & 63.0 & 84.5 & 5 \\
\hline Environment & 4.21 & 28.3 & 50.5 & 78.8 & 12 \\
\hline \multicolumn{6}{|l|}{ Satisfaction with: } \\
\hline \multicolumn{6}{|l|}{ Housing } \\
\hline Room layout & 4.16 & 42.1 & 40.2 & 82.3 & 6 \\
\hline Size & 4.10 & 39.3 & 40.5 & 79.8 & 10 \\
\hline Construction quality & 3.96 & 44.3 & 30.0 & 74.3 & 16 \\
\hline \multicolumn{6}{|l|}{ Living environment } \\
\hline Orderliness & 4.18 & 47.1 & 37.6 & 84.7 & 4 \\
\hline Peacefulness & 4.28 & 37.1 & 48.8 & 85.9 & 3 \\
\hline Air quality & 4.14 & 37.1 & 42.2 & 79.3 & 11 \\
\hline Safety & 4.35 & 43.5 & 46.8 & 90.3 & 1 \\
\hline \multicolumn{6}{|l|}{ Accessibility to: } \\
\hline Building & 4.33 & 40.3 & 48.8 & 89.1 & 2 \\
\hline Apartment & 4.10 & 43.0 & 38.1 & 81.1 & 8 \\
\hline \multicolumn{6}{|l|}{ Proximity of services and care } \\
\hline Relatives/friends & 4.14 & 43.2 & 38.5 & 81.7 & 7 \\
\hline Healthcare & 4.10 & 44.8 & 35.7 & 80.5 & 9 \\
\hline Long-term care & 3.96 & 51.6 & 26.0 & 77.6 & 14 \\
\hline Recreation/socializing & 4.01 & 42.8 & 34.3 & 77.1 & 15 \\
\hline Public amenities/services & 4.10 & 36.5 & 41.3 & 77.8 & 13 \\
\hline
\end{tabular}

Note: *Ranking according to the total share of ratings of 4 and 5 ( 1 = highest, $16=$ lowest).

The two attachment aspects had the highest average ratings and highest share of ratings of $5: 63 \%$ of respondents ascribed a rating of 5 to attachment to home and $50.5 \%$ to attachment to their living environment (see Table 2). However, in terms of the total share of ratings of 4 and 5 , and the ranking of all attachment and satisfaction aspects (sixteen), they only ranked fifth (attachment to home) and twelfth (attachment to environment). Satisfaction with safety and satisfaction with "external" physical accessibility ranked the highest. The former was rated 4 and 5 by $90.3 \%$ of the elderly, and the latter by $89.1 \%$. Satisfaction with peacefulness ranked third $(85.1 \%$ of ratings of 4 and 5). Aspects that had the lowest average satisfaction ratings ranked the lowest: access to long-term care services (77.6\%), opportunities for recreation and socializing (77.1\%) and construction quality (74.3\%).

Even though the share of those that reported lower attachment and satisfaction ratings is small, below the authors seek to establish the differences between them and those that reported higher ratings - that is, differences in age, settlement type, tenure and length of residence - and (if such differences do exist) whether these differences are statistically significant.

\subsection{Age}

As already mentioned in the theoretical part of this article, the survey by the American Association of Retired People showed that the share of those that would like to stay at home as long as possible increases with age. Meredith Driscoll (2011) argues that many researchers (Rubenstein, 1989; Fogel, 1992; Rowles \& Ravdal, 2002) ascribe this preference among the elderly to their home attachment. As already stated in the introduction and as confirmed by Duncan Case (1996), HansWerner Wahl (2003) and Wahl and Laura N. Gitlin (2003) the importance of one's home increases with age and so does one's attachment to it. As people age, they begin to increasingly feel part of their environment; they feel they belong to it and that their home is part of them. This is also confirmed by Graham D. Rowles (1983), who claims that the elderly develop a special attitude to their home, which makes them 
identify with it and perceive it as their extension. In this regard, Driscoll (2011) highlights a survey by Chris Gilleard et al. (2007), which showed that British seventy- and eightyyear-olds were more strongly attached to their homes than their younger counterparts. These findings can be further confirmed by the survey presented here. The statistical analysis showed a correlation between respondents' age and general attachment $(r=0.122 ; p=0.000)$. It also showed a correlation between age and satisfaction $(r=-0.084 ; p=0.012)$. In both cases, the correlation is weak, but statistically significant at $p=$ 0.01 and $p=0.05$. As anticipated, the correlation between age and general attachment is positive, and the correlation between age and general satisfaction is negative. This means that attachment to one's living environment increases with age, whereas satisfaction with it decreases. This finding makes sense considering that people's mobility decreases with age, due to which they may have problems accessing their homes or problems with accessibility within their wider environment. They may also have problems with limited mobility in their own homes if these are not appropriately architecturally adapted. In old age, people also seek more peace and safety because they feel more threatened and vulnerable. As they age, they also gradually lose their close friends, who die, and due to reduced mobility they often tend to maintain increasingly fewer contacts with people in their neighbourhood. The remoteness of public services may also present a major problem.

A detailed analysis of attachment shows that the elderly are somewhat more attached to their homes $(r=0.130 ; p=0.000)$ than their living environments $(r=0.095 ; p=0.004)$, which was also confirmed by Carmen Hidalgo and Bernarda Hernandez (2001) and Marie Lewicka (2005). Those that reported a very strong attachment to their homes were over ten years older on average (69.9 years) than those that rated their home attachment the lowest (59.5 years). No home attachment at all was only reported by respondents between the ages of fifty and sixty-nine. In terms of attachment to one's living environment, the average age difference between the two groups is smaller, but nonetheless amounts to 5.2 years (rating $1=64.8$ years, rating $5=70.0$ years).

More detailed statistical analysis of the correlation between age and individual aspects of satisfaction with housing and living environment shows that this correlation is negative in all cases. It is weak but statistically significant with regard to satisfaction with peacefulness of the environment $(r=-0.095$; $p=0.004)$, safety $(r=-0.092 ; p=0.006)$, accessibility of the housing $(r=-0.106 ; p=0.002)$, and opportunities for recreation and socializing $(r=-0.069 ; p=0.044)$. A correlation at $p=0.10$ is also evident with regard to satisfaction with "external" physical accessibility $(r=-0.055 ; p=0.099)$ and the proximity of relatives and friends $(r=-0.058 ; p=0.083)$.
The greatest difference in average age can be seen with regard to satisfaction with safety: the average age of those that are very dissatisfied with it is 68.3 years and the average age of those that are very satisfied with it is 85.3 years. The difference with regard to satisfaction with accessibility of housing is 5.9 years and with regard to satisfaction with the peacefulness of the environment this difference is 3.3 years.

\subsection{Length of residence in the home environment}

Some studies (Rollero \& De Picolli, 2010) did not show any correlation between age and attachment to the living environment. Rowles (1983) argues this may result from differences between the elderly that have lived at several locations over the course of their lives and the elderly that have only lived (and still live) in the place where they were born. This assumption is confirmed by Robert Hay (1998), who shows that differences in attachment do exist between individuals that live in their birthplace (they are more attached) and individuals that moved to a place later in life (they are less attached). Based on these findings, attachment and satisfaction were also defined in relation to the elderly's length of residence in their living environment. In addition to the studies already mentioned above, others (Riger \& Lavrakas, 1981; Sampson, 1988; Bonaiuto et al. 1999; Hidalgo \& Hernandez, 2001; Lewicka, 2010) also show that the elderly are more attached to their homes than young people and that this is connected with the time they have spent in a specific home or wider living environment. Other authors (McCool \& Martin, 1994; Bonaiuto et al., 1999; Lewicka, 2005, 2010; Stedman, 2006; Raymond et al., 2010) have also established a correlation between the length of one's residence in their living environment and their attachment to it.

As anticipated, the study presented in this article also shows a correlation between length of residence and attachment to the living environment $(r=0.166 ; p=0.000)$. The difference in the linear correlation in the attachment to home or the living environment is negligible. In both cases, the correlation is positive and statistically significant at $p=0.01$, which means that attachment to one's living environment increases with one's length of residence in it. The average length of residence of those that rated their home attachment 1 was 21.7 years, and among those that rated it 5 it was 16.2 years longer (i.e., 37.9 years). In terms of attachment to the living environment, this difference is even greater: 18.7 years. Statistically significant differences in the length of residence in one's home environment and their attachment to it can also be observed if the respondents that assigned a rating of 1 or 2 to their attachment to their home or living environment are combined into one group and those that rated it 4 or 5 are combined into 
a different group (respondents that rated it 3 were excluded from the analysis). Both $t$-tests (attachment to home: $t(769)=$ $-3.036, p=0.002$; attachment to the environment: $t(811)=$ $-3.265, p=0.001$ ) show differences at $p=0.01$ between the two groups in terms of the average length of residence: the difference in attachment to one's home is 7.5 years and the difference in attachment to one's living environment is 6.3 years.

With regard to satisfaction with the living environment, a correlation with length of residence was determined only in terms of satisfaction with construction quality $(r=-0.101$; $p=0.002)$ and peacefulness of the environment $(r=-0.111$; $p=0.001)$. In both cases, the correlation is negative, which means that the respondents that had lived in their homes longer were less satisfied with their construction quality and the peacefulness of the environment. Hence, for example, the average length of residence of those that were very satisfied with the peacefulness of their living environment was 35.2 years and of those that were very dissatisfied with it was 42.3 years. Correlation with the length of residence is also evident in relation to satisfaction with the proximity of relatives and friends; this correlation is positive, but only at $p=0.10$. In all other aspects of satisfaction, there were no differences between the elderly in terms of the length of their residence in their home environment. These findings have also been confirmed by Eigil Boll Hansen and Georg Gottschalk (2006), who argue that extending one's residence at the same location by several years makes individuals become attached to their homes and living environment, but it may also obscure any practical inconveniences (e.g., poor access and lack of adaptation).

\subsection{Type of settlement}

By studying a sample of the Australian population, Anton and Lawrence (2014) established that individuals in rural areas were more attached to their homes than those in urban areas. This is also supported by Lewicka (2005), who argues that there is a negative linear correlation between attachment and the size of the settlement; accordingly, individuals in smaller settlements are more attached to their homes than those in larger settlements or cities. A comparison of the elderly's general attachment to home and the living environment in this study also shows statistically significant differences between those in urban and rural areas $(t(913.832)=3.363, p=0.001)$. The rural elderly are generally more attached to their living environment $(M=4.41)$ than those in towns $(M=4.22)$. According to Lewicka (2005), this is due to the fact that the elderly in urban environments are usually less connected among themselves or have fewer social contacts and are included in fewer associations that bring people together than those in rural areas. The author refers to the same findings by other authors, such as John D. Kasarda and Morris Janowitz (1974),
Robert J. Sampson (1988), and Gene L. Theodori and A. E. Luloff (2000). With regard to the differences in attachment between rural and urban areas, Theodori and Luloff relied on late-nineteenth- and early-twentieth-century findings by social theorists, who showed growing concern due to increased urbanization, modernization and industrialization, and the impact of these processes on social solidarity and people's integration in communities. An attempt was also made to apply the ideas of these theorists, the most significant among whom were Ferdinand Tönnies, Georg Simmel and Louis Wirth, to the findings of this study. In their writings, these theorists highlighted that rural communities stimulated a higher level of solidarity and integration than urban environments, which is why people in these communities were more attached to the places they lived in (see Tönnies, 1887; Simmel, 1903; Wirth, 1938). According to Theodori and Luloff (2000), as part of his ideal conception of the social transformation from a community (Germ. Gemeinschaft) into a society (Germ. Gesellschaft), Tönnies (1887) argued that urbanization and industrialization processes had changed the essential characteristics of a society from communal attachment determined by natural will into associational attachment determined by rational will. Simmel (1903) expanded this theory by claiming that in the countryside people's rhythm of life and sensory perceptions are slower, more natural, more laid back and more smoothly flowing than in the city. Accordingly, people in metropolises have developed an indifference toward their living environment to protect themselves from rapid changes and stress, thus making possible their self-preservation. From Simmel's perspective, this indifference, which is reflected in the reserved personality of individuals in the urban environment, can also be manifested in the loss of attachment to the community and living environment. Despite this and other traditional views on urbanization, Theodori and Luloff (2000) argue that it is primarily Wirth's theory that defines the effects of the urban environment on individuals and their connectivity (see Wirth, 1938; Fischer, 1972; Christenson, 1979). According to Wirth (1938), the size, density and heterogeneity of the urban population are the characteristics that lead to weaker family ties, the replacement of primary contacts with secondary ones, a smaller emphasis on the social importance of the local community and, in this sense, a deterioration and loss of attachment with the community and hence a lower level of attachment to the individual's living environment compared to the countryside (Wirth, 1938; Fischer, 1972; Christenson, 1979).

The findings by social theorists presented above refer to the entire population and hence also the part discussed in this study. This is also confirmed by the results, which, in terms of attachment, even place the importance of the place of residence above the importance of age. Even though it was established that the correlation between a lower level of attachment and 
lower age is statistically significant and that the average age of rural respondents $(M=67.5)$ is statistically significantly lower $(t(901)=-4.964, p=0.000)$ than that of urban respondents $(M=70.8)$, those in the countryside reported greater general attachment to their living environment than their urban counterparts. In addition to the elderly's general attachment to their homes and living environments in rural and urban settlements, statistically significant differences can also be established if both attachment aspects are analysed separately; attachment to home: $t(908.303)=2.696, p=$ 0.007 ; and attachment to the environment: $t(910)=3.350$, $p=0.001$. In addition to differences, the average attachment ratings also reveal that, regardless of where they live, the elderly are more attached to their homes than to their living environment. The average rating of home attachment was higher in both the countryside $(M=4.50)$ and towns $(M=4.33)$ compared to attachment to the living environment (the average rating in the countryside was 4.33 and in towns it was 4.12). This finding partly contests the findings of the social theorists mentioned above, which shows that the countryside is also turning into a very heterogeneous place influenced by the urbanization process. Urbanization is reflected in the dissolution of the former solidarity within rural communities, increasing individualization and consequently also the social exclusion of the elderly (Lichter \& Brown, 2011; Walsh \& Ward, 2013).

In terms of satisfaction, the rural and urban elderly do not differ with regard to the housing aspects and aspects connected with physical accessibility within the environment, but they do differ in terms of satisfaction with the proximity of services and care $(t(832.518)=-7.162, p=0.000)$ and satisfaction with their living environment $(t(917)=5.223, p=0.000)$. However, this satisfaction proves to be exactly the opposite: the urban elderly tend to be more satisfied with the proximity of services and care $(M=4.20)$ than the rural elderly $(M=$ 3.90), whereas the latter tend to be more satisfied with their living environment $(M=4.35)$ than the urban dwellers $(M=$ 4.14). The rural elderly differ from their urban counterparts in terms of satisfaction with the peacefulness of the environment $(t(917)=4.043, p=0.000)$, air quality $(t(915)=7.284$, $p=0.000)$ and safety $(t(913)=3.568, p=0.000)$. No differences were found only in terms of satisfaction with the general orderliness of the environment: residents of both settlement types reported the same satisfaction rating in this regard $(M=$ 4.18). Based on the $t$-tests calculated, the greatest differences between both groups of the elderly in the average satisfaction rating with their environment can be seen in terms of their satisfaction with air quality: rural dwellers ascribed an average rating of 4.38 to this aspect, whereas the rating ascribed by the city dwellers was 3.95. This is followed by satisfaction with the peacefulness of the environment (the average rating for the countryside was 4.41 and for the urban areas it was 4.17) and satisfaction with safety $(M=4.44$ and 4.27 , respectively). Even greater differences between rural and urban dwellers were established in terms of their satisfaction with the proximity of services and care (with all four aspects in this category). The average satisfaction rating for each aspect was above 4 in urban areas, whereas in the countryside this rating was not exceeded for any of the aspects. The greatest difference was established in terms of satisfaction with the proximity of public services and amenities $(t(824.283)=-9.258, p=0.000)$; the average rating in the urban areas was 4.37 and in the countryside it was 3.79 . The two groups also differed significantly in terms of their satisfaction with the proximity of healthcare $(t(917)=-6.816$, $p=0.000)$ - the average rating in the countryside was 3.90 and in the urban areas it was 4.28 - and with the opportunities for recreation and socializing $(t(770.680)=-5.114, p=0.000)$, with average ratings of 4.16 and 3.82, respectively. Access to long-term care services $(t(684.749)=-5.732, p=0.000)$ was ascribed an average rating of 4.14 in towns and 3.78 in the countryside. This was also the lowest average rating that the rural elderly ascribed to any satisfaction aspect (e.g., in the city the lowest rating, 3.95, was ascribed to air quality).

\subsection{Tenure}

Saunders (1990: 39) argues that homeownership is "an emotional expression of autonomy, security, or personal identity", and hence homeowners are more emotionally attached to their homes than tenants. He adds that, by being able to maintain, take care of and improve their homes, the majority of homeowners feel a sense of satisfaction. According to George C. Galster (1987), by being able to arrange their homes to their taste they tend to feel freer and more autonomous than renters, and a living environment arranged this way is more likely to support their life cycles and increase their satisfaction with living and life in general. This is also confirmed by Peter $\mathrm{H}$. Rossi and Eleanora Weber (1996), who showed a statistical correlation between homeownership and higher self-esteem and happiness. According to Galster (1987), this is especially typical of the elderly, who also tend to be more satisfied with their real estate and living environment than renters, regardless of the characteristics involved (e.g., the cleanliness of the environment, and the size and condition of the home). In this regard, the longitudinal survey reported by Willam M. Rohe and Michale Stegman (1994) and Willam M. Rohe and Victoria Basolo (1997) is especially interesting. It showed that, after purchasing a home, new owners reported a statistically significant increase in their life satisfaction than those that remained renters. The same owners also reported a higher satisfaction rating three years later, regardless of whether their real estate was in less favoured neighbourhoods, which by then they had already experienced themselves. Willam M. Rohe et al. (2001) argue that the characteristics of one's home and living 
environment were also taken into account by other researchers in their surveys on satisfaction (Morris et al., 1976; Kinsey \& Lane, 1983; Varady, 1983; Lam, 1985; Danes \& Morris, 1986). In all cases, it turned out that homeowners are more satisfied than renters.

As expected and in accordance with the findings of other researchers, the case investigated here also shows statistically significant differences in the elderly's attachment to their home in terms of tenure $(t(907)=2.353, p=0.019)$. On average, homeowners ascribed a rating of 4.42 to their home attachment - this was also the highest average rating ascribed by homeowners to any attachment and satisfaction aspect - and the average rating ascribed by renters was 3.89. Differences in the average ratings can also be observed in their attachment to the living environment and in certain satisfaction aspects - for example, in all three aspects of housing satisfaction (size, layout of rooms and construction quality) and satisfaction with peacefulness of the environment and the proximity of relatives and friends. Even though these differences cannot be statistically proven, greater satisfaction and attachment (just like with the home attachment above) were reported by homeowners in all of these cases.

Because the elderly also had the opportunity to express their opinions or provide arguments for their answers, and the interviewers wrote down their observations, certain qualitative information was also obtained during the survey in addition to quantitative data. Among other things, this revealed that most respondents were extremely attached to their houses (even more than to apartments) because they had largely helped build them themselves "with a great deal of sacrifice and hard work," as they often reported. A high rate of self-construction was typical of Slovenia during the communist period. This is also evident from the ratio of house to apartment ownership among the respondents: $74.8 \%$ house owners versus $25.2 \%$ apartment owners. A detailed statistical analysis was carried out in order to check the interviewers' observations. The analysis revealed that house owners in fact reported a statistically significant higher attachment rating than apartment owners $(t(887)=2.633, p=0.009)$. The average attachment rating ascribed by the former was 4.46 and that ascribed by the latter was 4.28. This can also be confirmed based on another question included in the survey, in which house owners ascribed a higher rating to the importance of their home than apartment owners: they ascribed an average rating of 4.14 to the statement that their home represents a life achievement to them, whereas the rating ascribed by the apartment owners was 3.91. The difference in the average rating of both groups is statistically significant at $p=0.05(t(876)=2.897, p=0.004)$. An even greater statistically significant differences in the importance of the home can be observed between homeowners and renters (the rating ascribed by the former was 4.08 and that ascribed by the latter was 2.84).

\section{Conclusion}

As highlighted by Golant (1982), the living environment represents a major portion of their overall life path for the elderly. Vasara (2015: 59) argues that accordingly "homes are more than just dwellings, they are filled with personal meanings." It is no coincidence that the elderly often develop extremely deep feelings toward their home; they are very attached to it and are satisfied with living in it (often precisely because they are so attached to it). The findings of various experts regarding the elderly's attachment to and satisfaction with their living environment were also examined in this study. The authors were interested in whether the elderly in Slovenia were also attached to and satisfied with their homes, how intense this attachment and satisfaction was and whether there were any differences in age, length of residence, settlement type and tenure among the elderly in this regard. As expected, the findings revealed that the elderly in Slovenia are also generally very attached to their homes and are very satisfied with them, and that there are differences among them in this regard. Specifically, a higher attachment rating is typical of those that are older, have lived in their living environments for an extended period of time, live in the countryside and are homeowners. Differences are also evident in individual aspects of satisfaction with the "immediate" and "wider" living environment, although not with every aspect. Hence, for example, in relation to the length of residence, differences among the elderly are evident only with regard to satisfaction with construction quality and the peacefulness of the environment: those that have lived in their homes longer are less satisfied with their construction quality and the peacefulness of the environment. In terms of tenure, it turned out that there are differences in all three aspects of housing satisfaction (size, layout of rooms and construction quality) as well as in satisfaction with the peacefulness of the environment and the proximity of relatives and friends: in all cases, the homeowners reported higher satisfaction; however, these differences cannot be statistically proven. With regard to settlement type, the rural and urban elderly do not differ in terms of housing aspects and aspects referring to the physical accessibility in the environment; however, they do differ in terms of satisfaction with the proximity of services and care and satisfaction with the living environment: as expected, the urban elderly are more satisfied with the proximity of services and care, and the rural elderly are more satisfied with the environment. With regard to age, differences among the respondents were observed with all satisfaction aspects, in which satisfaction with housing and living environment increases with age, as expected. 
Even though statistical analyses have shown statistically significant differences among the elderly in terms of their attachment to and satisfaction with their living environment, it has to be highlighted (once again) that the elderly are very attached to their homes and are very satisfied with them, and that in most cases the only difference is between "great and even greater attachment and great and even greater satisfaction." Therefore, the elderly should be allowed to remain in their living environment as long as possible. Because the elderly are attached to and satisfied with their homes, this can have a number of positive effects, especially on their wellbeing and psychophysical fitness. According to Jordana L. Maisel et al. (2008), research has shown that independent life stimulates successful aging by improving health and increases the elderly's life satisfaction and self-esteem, which can postpone their use of institutional care. Hence, aging at home or aging in place is the most desirable form of housing or living for the elderly. However, the preferences of the elderly to live in their own homes not only have positive aspects, but also come with a number of obstacles, such as a) the inappropriate setup of dwellings (e.g., inappropriate bathroom furnishings, thresholds and other architectural obstacles), b) difficult access to their homes (e.g., stairs and multi-storey buildings with no lifts), c) inappropriate location of the dwelling (e.g., remoteness of public services and inappropriate transport connections, resulting in the elderly becoming increasingly isolated, staying in their homes more often and becoming dependent on others for services), and d) maintenance of dwellings (if they are homeowners) and the coverage of current and annual housing costs. In such cases, home attachment becomes an emotional, physical and economic burden. However, precisely because of their strong attachment, the elderly refuse to move elsewhere; they perceive this as a traumatic experience (Kerbler, 2012). Therefore, despite their poor quality of living and dissatisfaction, they continue to live in their homes, even though they could improve the quality of their lives by moving into a different living environment.

Understanding the elderly's attitudes toward moving house in particular will be the main topic of further analyses as part of this study. Other factors based on which the elderly differ from one another in terms of their attachment to and satisfaction with their living environment (e.g., economic status, its maintenance level, education, etc.) will have to be analysed in greater detail, and in-depth statistical methods (e.g., factor analysis and multiple regression) will have to be used in order to determine the interdependence of various factors (that have been analysed separately in this study) or their mutual effects on attachment and satisfaction.

\section{Boštjan Kerbler}

Urban Planning Institute of the Republic of Slovenia, Ljubljana,

Slovenia

E-mail: bostjan.kerbler@uirs.si
Richard Sendi

Urban Planning Institute of the Republic of Slovenia, Ljubljana,

Slovenia

E-mail: richard.sendi@uirs.si

Maša Filipovič Hrast

University of Ljubljana, Faculty of Social Sciences, Ljubljana, Slovenia E-mail: masa.filipovic@fdv.uni-lj.si

\section{Notes}

${ }^{[1]}$ The five-point Likert scale is an ordinal scale, but there is no consensus in the literature on whether it can be treated as an interval scale (Jamieson, 2004; Norman, 2010). However, because the ordinal scale is the most frequently used scale in the social sciences due to the predominance of opinion scales, according to the recommendations by the Social Informatics Centre (SIn. Center za družboslovno informatiko, 2017) and assuming that the differences between categories are the same, the ordinal scale can also be used to calculate the averages and variance, making it similar to an interval scale.

\section{Acknowledgments}

We would like to thank the Slovenian Research Agency for funding the basic research project Inovativne oblike bivanja za starejše ljudi v Sloveniji (Innovative Forms of Living Environments for the Elderly in Slovenia; no. J5-6824), which was carried out from 2014 to 2017. The Urban Planning Institute of the Republic of Slovenia and the Ljubljana Faculty of Social Sciences were involved in this project. We would also like to thank Karina Sirk, a student at the Faculty of Social Sciences, for her assistance in collecting and analysing literature.

\section{References}

Allardt, E. (1993) Having, loving, being: An alternative to the Swedish model of welfare research. In: Nussbaum, M. \& Sen, A. (eds.) The quality of life, pp. 88-94. Oxford, Clarendon Press. DOI: 10.1093/0198287976.003.0008

American Association of Retired People (2000) Fixing to stay: A national survey of housing and home modification issues. Washington, DC, Matthew Greenwald and Associates.

Anton, C. E. \& Lawrence, C. (2014) Home is where the heart is: The effect of place of residence on place attachment and community participation. Journal of Environmental Psychology, 40, pp. 451-461. DOI: 10.1016/j.jenvp.2014.10.007

Atkinson, T., Cantillon, B., Marlier, E. \& Nolan, B. (2002) Social indicators. The EU and social inclusion. Oxford, Oxford University Press. DOI: 10.1093/0199253498.001.0001

Barlow, J. \& Duncan, S. (1994) Success and failure in housing provision. European systems compared. Oxford, Pergamon Press.

Bonaiuto, M., Aielllo, A., Perugini, M., Bonnes, M. \& Ercolani, A. P. (1999) Multidimensional perception of residential environment quality and neighbourhood attachment in the urban environment. Journal of Environmental Psychology, 19(4), pp. 331-352. DOI: 10.1006/jevp.1999.0138

Boškić, R. (2002) Krepitev moči na stanovanjskem področju. In: Mandič, S. \& Filipovič, M. (eds.) Stanovanjske študije, pp. 21-43. Ljubljana, Univerza v Ljubljani, Fakulteta za družbene vede.

Bricker, K. S. \& Kerstetter, D. L. (2000) Level of specialisation and place attachment: An explanatory study of Whitewater recreationists. Leisure Sciences, 20(4), pp. 233-257. 
Brown, G. \& Raymond, C. (2007) The relationship between place attachment and landscape values: Towards mapping place attachment. Applied Geography, 27(2), pp. 89-111. DOI: 10.1016/j.apgeog.2006.11.002

Case, D. (1996): Contributions of journeys away to the definition of home: An empirical study of a dialectical process. Journal of Environmental Psychology, 16(1), pp. 1-15. DOI: 10.1006/jevp.1996.0001

Center za družboslovno informatiko (2017) Celovita podpora anketnemu procesu. Ljubljana, Univerza v Ljubljani, Fakulteta za družbene vede. Available at: www.1ka.si (accessed 17 May 2017).

Christenson, J. A. (1979) Urbanism and community sentiment: Extending Wirth's model. Social Science Quarterly, 60(3), pp. 387-400.

Clough, R., Leamy M., Miller, V. \& Bright, L. (2004) Housing decisions in later life. Basingstoke, UK, Palgrave Macmillan.

Costa-Font, J. (2013) Housing-related well-being in older people: The impact of environmental and financial influences. Urban Studies, 50(4), pp. 657-673. DOI: 10.1177/0042098012456247

Czischke, D. \& Gruis, V. (2007) Managing social rental housing in the EU in a changing policy environment: Towards a comparative study. Paper presented at the European Network for Housing Research Seminar, 20-21 April, Dublin, Ireland. Typescript.

Daly, H. E. (2007) Ecological economics and sustainable development: Selected essays of Herman Daly. Cheltenham, UK, Edward Elgar Publishing Limited. DOI: 10.4337/9781847206947

Danes, S. \& Morris, E. (1986) Housing status, housing expenditures and satisfaction. Housing and Society, 13(1), pp. 32-43.

DOI: 10.1080/08882746.1986.11429976

de Jong, P., Rouwendal, J., Van Hattum, P. \& Brouwer, A. (2012) Housing preferences of an ageing population. Investigation in the diversity among Dutch older adults. Tilburg, Netspar.

Doling, J. (1999) Housing policies and the little tigers: How do they compare with the other industrialised countries? Housing Studies, 14(2), pp. 229-250. DOI: 10.1080/02673039982939

Doling, J. (2006) A European housing policy? European Journal of Housing Policy, 6(3), pp. 335-349. DOI: 10.1080/14616710600973169

Domanski, H., Ostrowska, A., Przybysz, D., Romaniuk, A. \& Krieger, H. (2006) First European quality of life survey. Social dimensions of housing. Dublin, European Foundation for Improvement of Living and Working Conditions.

Driscoll, M. (2011) Attachment to place: Individual differences in a house becoming a home. Doctoral thesis. Kent, Kent State University College and Graduate School of Education, Health, and Human Services.

Dupuis, A. \& Thorns, D. C. (1996) Meanings of home for older homeowners. Housing Studies, 11(4), pp. 485-501. DOI: 10.1080/02673039608720871

Erikson, R. (1993) Description of inequality. The Swedish approach to welfare research. In: Craven Nussbaum, M. \& Sen, K. A. (eds.) The quality of life, pp. 67-83. Oxford, Oxford University Press.

DOI: 10.1093/0198287976.003.0006

Fahey, T., Nolan, B. \& Maitre, B. (2004) Housing expenditure and income poverty in EU countries. Journal of Social Policy, 33(3), pp. 437-454. DOI: $10.1017 /$ S0047279404007767

Field, A. (2009) Discovering statistics using IBM SPSS statistics. London, SAGE Publications.

Fischer, C. S. (1972) Urbanism as a way of life: A review and an agenda. Sociological Methods \& Research, 1(2), pp. 187-242. DOI: $10.1177 / 004912417200100203$
Fogel, B. S. (1992) Psychological aspects of staying at home. Generations, 16(3), pp. 15-19.

Fried, M. (2000): Continuities and discontinuities of place. Journal of Environmental Psychology, 20(3), 193-205. DOI: 10.1006/jevp.1999.0154

Galster, G. C. (1987) Homeowners and neighborhood reinvestment. Durham, NC, Duke University Press.

Gilleard, C., Hyde, M. \& Higgs, P. (2007) The impact of age, place, aging in place, and attachment to place on the well-being of the over 50s in England. Research on Aging, 29(6), pp. 590-605. DOI: $10.1177 / 0164027507305730$

Golant, S. M. (1982) The residential location and spatial behaviour of the elderly. Chicago, University of Chicago Press.

Hansen, E. B. \& Gottschalk, G. (2006) What makes older people consider moving house and what makes them move? Housing, Theory and Society, 23(1), pp. 34-54. DOI: 10.1080/14036090600587521

Harris, P. B., Werner, C. M., Brown, B. B. \& Ingebritsen, D. (1995) Relocation and privacy regulation: A cross-cultural analysis. Journal of Environmental Psychology, 15(4), pp. 311-320. DOI: 10.1006/jevp.1995.0027

Hårsman, B. \& Quigley, J. M. (1991) Housing markets and housing institutions: An international comparison. Boston, Kluwer Academic Publishing. DOI: 10.1007/978-94-011-3915-1

Hay, R. (1998) Sense of place in developmental context. Journal of Environmental Psychology, 18(1), pp. 5-29. DOI: 10.1006/jevp.1997.0060

Hernandez, B., Hidalgo, M. C. \& Ruiz, C. (2013) Theoretical and methodological aspects of research on place attachment. In: Manzo, L. \& Devine-Wrights, P. (eds.) Place attachment: Advances in theory, methods and applications, pp. 125-137. London, Routledge.

Heywood, F., Oldman, C. \& Means, R. (2002) Housing and home in later life. Buckingham, UK, Open University Press.

Hidalgo, M. C. \& Hernandez, B. (2001) Place attachment: Conceptual and empirical questions. Journal of Environmental Psychology, 21(3), pp. 273-281. DOI: 10.1006/jevp.2001.0221

Hwang, S., Fuller-Thomson, J. D., Bryant, T., Habib, W. \& Regoeczi, W. (1999) Housing and population health: A review of the literature. Ottawa, Mortgage and Housing Corporation.

Jamieson, S. (2004) Likert scales: How to (ab)use them. Medical Education, 38(12), pp. 1217-1218. DOI: 10.1111/j.1365-2929.2004.02012.x

Jorgenson, B. S. \& Stedman, R. C. (2001) Sense of place as an attitude: Lakeshore owners attitudes towards their properties. Journal of Environmental Psychology, 21, pp. 233-248. DOI: 10.1006/jevp.2001.0226

Kasarda, D. J. \& Janowitz, M. (1974) Community attachment in mass society. American Sociological Review, 39(3), pp. 328-339. DOI: $10.2307 / 2094293$

Kerbler, B. (2012) Ageing at home with the help of information and communication technologies. Acta Geographica Slovenica, 52(1), pp. 165-188. DOI: 10.3986/AGS52107

Kerbler, B. (2014) Housing for the elderly in Slovenia: Analysis of the most common forms. Theoretical and Empirical Researches in Urban Management, 9(2), pp. 87-103.

Kinsey, J. \& Lane, S. (1983) Race, housing attributes, and satisfaction with housing. Housing and Society, 10(3), pp. 98-116. DOI: $10.1080 / 08882746.1983 .11429932$

Kleinman, M., Matznetter, W. \& Stephens, M. (eds.) (1998) European integration and housing policy. London, Routledge. 
Kyle, G., Graefe, A. \& Manning, R. (2005) Testing the dimensionality of place attachment in recreational settings. Environment and Behavior, 37(2), pp. 153-177. DOI: 10.1177/0013916504269654

Kyle, G., Theodori, G. L., Absher, J. D. \& Jun, J. (2010) The influence of home and community attachment on firewise behaviour. Society and Natural Resources, 23, pp. 1-18. DOI: 10.1080/08941920902724974

Lalli, M. (1992) Urban-related identity: Theory, measurement and empirical findings. Journal of Environmental Psychology, 12(4), pp. 285-303. DOI: $10.1016 /$ S0272-4944(05)80078-7

Lam, J. (1985) Type of structure, satisfaction and propensity to move. Housing and Society, 12(1), pp. 32-44.

DOI: $10.1080 / 08882746.1985 .11429958$

Leckie, S. (1994) Towards an international convention on housing rights: Options at Habitat II. Washington, DC, American Society of International Law.

Lewicka, M. (2005) Ways to make people active: The role of place attachment, cultural capital, and neighbourhood ties. Journal of Environmental Psychology, 25(4), pp. 381-395. DOI: 10.1016/j.jenvp.2005.10.004

Lewicka, M. (2010) What makes neighbourhood different from home and city? Effects of place scale on place attachment. Journal of Environmental Psychology, 30(1), pp. 35-51. DOI: 10.1016/j.jenvp.2009.05.004

Lewicka, M. (2011) Place attachment: How far have we come in the last 40 years? Journal of Environmental Psychology, 31(3), pp. 207-230. DOI: 10.1016/j.jenvp.2010.10.001

Lichter, D. L. \& Brown, D. L. (2011) Rural America in an urban society: Changing spatial and social boundaries. Annual Review of Sociology, 37(1), pp. 565-592. DOI: 10.1146/annurev-soc-081309-150208

Maisel, J., Smith, E. \& Steinfeld, E. (2008) Increasing home access: Designing for visitability. Washington, DC, Center for Inclusive Design and Environmental Access.

Mandič, S. (1996) Stanovanje in država. Ljubljana, Znanstveno in publicistično središče.

Mandič, S. (2011) Stanovanje in blaginja stareǰ̌ih: primerjava Slovenije z izbranimi evropskimi državami. In: Mandič, S. \& Filipovič Hrast, M. (eds.) Blaginja pod pritiski demografskih sprememb, pp. 85-105. Ljubljana, University of Ljubljana, Faculty for Social Sciences.

Mandič, S. (2015) Stanovanjske razmere in mobilnost starejšega prebivalstva - Slovenija v primerjalni perspektivi. In: Majcen, B. \& Mašič, S. (eds.) Značilnosti starejšega prebivalstva v Sloveniji - prvi rezultati, pp. 183-195. Ljubljana, Institute for Economic Research.

Marcuse, P. (1987) The other side of housing: Oppression and liberation. Stockholm, Almqvist and Wiksell International.

McCool, S. F. \& Martin, S. R. (1994) Community attachment and attitudes toward tourism development. Journal of Travel Research, 32(3), pp. 29-34. DOI: 10.1177/004728759403200305

Mesch, G. S. \& Manor, O. (1998) Social ties, environmental perception, and local attachment. Environment and Behaviour, 30(4), pp. 504-519. DOI: $10.1177 / 001391659803000405$

Milligan, V. R. (2003) How different? Comparing housing policies and housing affordability consequences for low-income households in Australia and the Netherlands. Utrecht, Utrecht University.

Mishra, S., Mazumdar, S. \& Suar, D. (2010) Place attachment and flood preparedness. Journal of Environmental Psychology, 30(2), pp. 187-197. DOI: 10.1016/j.jenvp.2009.11.005

Moore, R. L. \& Graefe, A. R. (1994) Attachment to recreation settings: The case of rail-trail users. Leisure Sciences, 16(1), pp. 17-31. DOI: 10.1080/01490409409513214
Morris, E., Crull, S. \& Winter, M. (1976) Housing norms, housing satisfaction and the propensity to move. Journal of Marriage and the Family, 38(2), pp. 309-320. DOI: 10.2307/350390

Norman, G. (2010) Likert scales, levels of measurement and the "laws" of statistics. Advances in Health Science Education, 15(5), pp. 625-632. DOI: 10.1007/s10459-010-9222-y

Raymond, C., Brown, G. \& Weber, D. (2010) The measurement of place attachment: Personal, community, and environmental connections. Journal of Environmental Psychology, 30(4), pp. 422-434. DOI: 10.1016/j.jenvp.2010.08.002

Riger, S. \& Lavrakas, P. J. (1981) Community ties: Patterns of attachment and social interaction in urban neighbourhoods. American Journal of Community Psychology, 9(1), pp. 55-66. DOI: 10.1007/BF00896360

Rohe, W. M. \& Basolo, V. (1997) Long-term effects of homeownership on the self-perceptions and social interaction of lowincome persons. Environment and Behavior, 29(6), pp. 793-819. DOI: $10.1177 / 0013916597296004$

Rohe, W. M. \& Stegman, M. (1994) The impact of home ownership on the social and political involvement of low-income people. Urban Affairs Quarterly, 30(September), pp. 152-172. DOI: $10.1177 / 004208169403000108$

Rohe, W. M., Van Zandt, S. \& McCarthy, G. (2001) The social benefits and costs of homeownership: A critical assessment of the research. Washington, DC, Joint Center for Housing Studies of Harvard University.

Rollero, C. \& De Picolli, N. (2010) Does place attachment affect social well-being? Revue européenne de psychologie appliquée, 60(4), pp. 233238.

Rossi, P. H. \& Weber, E. (1996) The social benefits of homeownership: Empirical evidence from national surveys. Housing Policy Debate, 7(1), pp. 1-35. DOI: 10.1080/10511482.1996.9521212

Rowles, G. D. (1983) Place and personal identity in old age: Observations from Appalachia. Journal of Environmental Psychology, 3(4), pp. 299-313. DOI: 10.1016/S0272-4944(83)80033-4

Rowles, G. D. \& Ravdal, H. (2002) Aging, place, and meaning in the face of changing circumstances. In: Weiss, R. S. \& Bass, S. A. (eds.) Challenges of the third age: Meaning and purpose in later life, pp. 81-114. New York, Oxford University Press.

Rubenstein, R. L. (1989) The home environments of older people: A description of the psychosocial processes linking person to place. The Journal of Gerontology: Social Sciences, 44(2), pp. 45-53.

DOI: $10.1093 /$ geronj/44.2.545

Salomon, E. (2010) Housing policy solutions to support aging in place. Washington, DC, American Association of Retired People Public Policy Institute.

Sampson, R. J. (1988) Local friendship ties and community attachment in mass society: A multilevel systemic model. American Sociological Review, 53(5), pp. 766-779. DOI: 10.2307/2095822

Saunders, P. (1990) A nation of home owners. London, Unwin Hyman.

Saunders, P. \& Williams, P. (1988) The constitution of the home. Housing Studies, 3(1), pp. 81-91. DOI: 10.1080/02673038808720618

Sendi, R., Černič Mali, B., Jakoš, A. \& Filipović, M. (2003) Stanovanjske potrebe upokojencev in drugih starejših ljudi. Ljubljana, Urban Planning Institute of the Republic of Slovenia.

Shamai, S. (1991) Sense of place: An empirical measurement. Geoforum, 22(3), pp. 347-358. DOI: 10.1016/0016-7185(91)90017-K

Simmel, G. (1950) The metropolis and mental life. In: Wolff, K. H. (ed.) The sociology of Georg Simmel, pp. 409-424. New York, Free Press. 
Somerville, P. (1997) The social construction of home. Journal of Architectural and Planning Research, 14(3), pp. 225-245.

Stedman, R. C. (2006) Understanding place attachment among second home mobility and well-being. Journal of Social Issue, 38, pp. 149-171.

Stokols, D. \& Shumaker, S. A. (1982) The psychological context of residential mobility and well-being. Journal of Social Issues, 38(3), pp. 149171. DOI: $10.1111 /$ j.1540-4560.1982.tb01776.x

Štuhec, J. I. \& Fras, M. (2010) Različne oblike bivanja za tretjo generacijo. Kakovostna starost, 13(3), pp. 3-15.

Tartaglia, S. (2012) Different predictors of quality of life in urban environments. Social Indicators Research, 113(3), pp. 1045-1053. DOI: 10.1007/s11205-012-0126-5

Theodori, G. L. \& Luloff, A. E. (2000) Urbanization and community attachment in rural areas. Society and Natural Resources, 13(5), pp. 399420. DOI: $10.1080 / 089419200403839$

Tönnies, F. (1887) Community and society: Gemeinschaft and Gesellschaft. New York, Harper \& Row.

Trentelman, C. (2009) Place attachment and community attachment: A primer grounded in the lived experience of a community sociologist. Society and Natural Resources, 22(3), pp. 191-210. DOI: 10.1080/08941920802191712

Tuan, Y. E. (1980) Rootedness versus sense of place. Landscape, 24, pp. 3-8.

Varady, D. (1983) Determinants of residential mobility decisions. Journal of the American Planning Association, 49(2), pp. 181-199. DOI: 10.1080/01944368308977063

Vasara, P. (2015) Not ageing in place: Negotiating meanings of residency in age-related housing. Journal of Aging Studies, 35, pp. 55-64. DOI: 10.1016/j.jaging.2015.07.004

Wahl, H. W. (2003) Place attachment across the life span. In: Miller, J. R., Lerner, R. M., Schiamber, L. B. \& Anderson, P. M. (eds.) Encyclopedia of human ecology, pp. 569-572. Santa Barbara, CA, ABC-Clio, Inc.

Wahl, H. W. \& Gitlin, L. N. (2003) Future developments in living environments for older people in the U.S. and Germany: Potential and constraints. In: Schaie, K. W., Wahl, H. W., Mollenkopf, H. \& Oswald, F. (eds.) Aging independently: Living arrangements and mobility, pp. 281-301. New York, Springer.

Walsh, K. \& Ward, P. (2013) Social exclusion and ageing in rural areas: Patterns and implications. Galway, Irish Centre for Social Gerontology.

Williams, D. R., Patterson, M. E., Roggenbuck, J. W. \& Watson, A. E. (1992) Beyond the commodity metaphor: Examining emotional and symbolic attachment to place. Leisure Sciences, 14(1), pp. 29-46. DOI: 10.1080/01490409209513155

Williams, D. R. \& Vaske, J. J. (2003) The measurement of place attachment: Validity and generalizability of a psychometric approach. Forest Science, 49(6), pp. 830-841.

Wirth, L. (1938) Urbanism as a way of life. American Journal of Sociology, 44(1), pp. 1-24. DOI: 10.1086/217913 